\title{
Parâmetros fisiológicos da placenta em éguas da raça Mangalarga Marchador
}

Isabela Syllos Campos ${ }^{[a]}$, Guilherme Nunes de Souza ${ }^{[b]}$, Gustavo Mendes Gomes[ ${ }^{[c]}$, Aline Emerim Pinna ${ }^{[a]}$, Ana Maria Reis Ferreira $^{[a]}$

\footnotetext{
[a] Universidade Federal Fluminense (UFF), Niterói, RJ, Brasil

[b] Empresa Brasileira de Pesquisa Agropecuária (EMBRAPA), Juiz de Fora, MG, Brasil

[c] Universidade Severino Sombra (USS), Vassouras, RJ, Brasil
}

*Autor correspondente

e-mail: isabelasyllos@ig.com.br

\section{Resumo}

Oacompanhamento gestacional daséguaséimprescindível para evitar perdas embrionárias e fetais. A placenta da égua é definida como um órgão formado por tecidos maternos e fetais, com a função de trocas metabólicas entre mãe e feto. Os equinos são os únicos que apresentam um grande número de causas não infecciosas de abortamentos relacionados à aparente falta de reserva placentária e deficiência microcotiledonária. A ultrassonografia transretal da espessura da junção útero-placentária é uma ferramenta de diagnóstico precoce de anormalidades placentárias e pode ser utilizada para o acompanhamento gestacional. Os exames macroscópicos e microscópicos da placenta pós-parto têm caráter de diagnóstico definitivo para patologias placentárias e permitem a avaliação das características fisiológicas da placenta. A raça Mangalarga Marchador é brasileira e possui um valor social e comercial muito alto dentro do país, e utiliza em larga escala as mais avançadas biotecnologias da reprodução. 0 objetivo do estudo foi avaliar mensalmente a espessura da junção útero-placentária das éguas da raça Mangalarga Marchador, do quinto mês de gestação até o mês do parto, com ultrassonografia convencional e anátomo-histopatologia das placentas pós-parto. Foram utilizadas sete éguas com gestação dentro dos padrões fisiológicos, com idade entre 5 a 10 anos. Na avaliação ultrassonográfica transretal, as junções útero-placentárias foram monitoradas mensalmente até o mês do parto e as medidas foram feitas entre o meio do ramo da artéria uterina e o fluído alantoideano, em três pontos, com médias entre eles na escala de milímetro. As placentas foram avaliadas pós-partos, macroscopicamente, e foram coletados sete fragmentos de regiões diferentes para o exame microscópico. As médias da espessura das junções útero-placentárias aumentaram a cada mês gestacional até o décimo primeiro mês, mês do parto. Todas as avaliações se mantiveram com média de 5,27 mm, permanecendo 
dentro do intervalo de confiança de 95\%. Os dados deste estudo ficaram próximos dos estudos com outras raças de éguas. As avaliações morfológicas das sete placentas pós-parto não apresentaram alterações compatíveis com patologias durante a gestação, e mantiveram-se dentro dos parâmetros fisiológicos. Assim como na ultrassonografia das junções útero-placentárias, não foram encontradas alterações significativas nas espessuras das junções útero-placentárias e imagens anormais para o padrão fisiológico, diferente em estudos de patologias placentárias com outras éguas, que apresentaram na imagem da junção úteroplacentária aumento acentuado da espessura, infiltrados inflamatórios na junção útero-placentária e no líquido alantoideano, abortamento em idade gestacional avançada e alterações morfológicas nas placentas pós-parto. 0 presente estudo concluiu que as avaliações das sete éguas da raça Mangalarga Marchador e suas respectivas placentas apresentaram padrões fisiológicos durante a gestação.

Palavras-chave: Gestação. Placenta. Ultrassonografia. 